\title{
Research Article: An economic analysis of SRI and non-SRI paddy cultivation in Vellore district of Tamil Nadu
}

\author{
口. LOGANATHAN, S. NANDHAKUMAR AND G. MARIAPPAN
}

Article Chronicle:

Received :

11.07.2017;

Accepted :

26.07.2017

\section{KEY WoRDS :}

Cost, Returns, Production function, Cost of cultivation, Garrett's score, SRI, Non-SRI
SUMMARY : Rice commends recognition, as a supreme commodity to mankind, because rice is truly life, culture, a tradition and a means of livelihood to millions.Major objectives are to analyse the socio economic impact of SRI and traditional rice cultivation and to estimate the cost and returns of paddy in SRI and their comparison with those in conventional methodin Vellore district of Tamil Nadu.Two major paddy growing blocks were selected. From each block, six major paddy growing villages was selected. Totally ten farmers were selected from each village comprising five farmers for SRI method and five farmers for traditional method of rice cultivation and the total sample size was 120.Descriptive statistical analysis, Garrett's Ranking Technique,etc was used the tools of analysis in research.About 55 per cent of the sample farmers had more than 20 years of experience in rice farming and only about 14 per cent of the sample farmers had less than 15 years of experience. The per hectare cost of cultivation (Rs.83,842.80) for SRI paddy was less when compared to that (Rs.87,742.88) of traditional paddy. The amount of fixed cost was Rs.8,868.90 and Rs.11,421.90 for traditional and SRI paddy farmers. The yield per hectare realized in traditional method was 6.07 tonnes. The paddy yield realized by SRI paddy farmers was 7 tonnes per hectare.High labour requirement was the major constraint in practicing SRI method.

How to cite this article : Loganathan, R., Nandhakumar, S. and Mariappan, G. (2017) An economic analysis of SRI and non-SRI paddy cultivation in Vellore district of Tamil Nadu. Agric. Update, 12 (TECHSEAR-4): 10021007; DOI: 10.15740/HAS/AU/12.TECHSEAR (4)2017/1002-1007.
Author for correspondence :

\section{R. LOGANATHAN}

Department of

Agriculture,

Adhiparasakthi

Agricultural College,

(T.N.A.U.) VELLORE

(T.N.) INDIA

See end of the article for

authors' affiliations 